\title{
ANALISIS RED CLAUSE KONTRAK KONSTRUKSI APBD DENGAN FIDIC RED BOOK 1999
}

oleh :

\author{
Randy Angga Erland Kesek \\ Teknik Sipil Universitas Tarumanagara \\ Email : randykesek@yahoo.com \\ Sarwono Hardjomuljadi \\ Teknik Sipil Universitas Mercu Buana \\ Email : sarwonohm2@yahoo.co.id
}

\begin{abstract}
Abstrak : Industri konstruksi saat ini telah menjadi sangat kompleks dan berisiko tinggi, sehingga diperlukan ikatan kerja yang baik dan berdasar hukum. Di Indonesia sendiri terjadi banyak kasus klaim dan sengketa konstruksi. Hal ini diakibatkan karena adanya perbedaan presepektif mengenai pasal-pasal dalam kontrak konstruksi dan kurangnya pemahaman tentang kontrak konstruksi tersebut. Setiap proyek konstruksi di daerah menggunakan dana APBD dimana setiap daerah membuat kontrak konstruksi sendiri sesuai dengan kebutuhan proyek konstruksi di daerah tersebut, sehingga setiap kontrak konstruksi yang dibuat berbeda-beda sehingga dapat berpotensi terjadinya klaim dan sengketa. Manfaat dari penelitian diharapkan dapat memberikan informasi untuk pengembangan kontrak konstruksi di kabupaten Halmahera Utara. Penelitian ini adalah penelitian mixed method, diawali dengan literature review. Uji pakar dilakukan dengan menggunakan Teknik Delphi. Kuisioner disusun berdasarkan studi literatur terhadap jurnal, buku dan penelitian terdahulu. Kuesioner menggunakan skala Likert berskala 6. Analisis faktor dilakukan dengan menggunakan SPSS 23.0 untuk menemukan faktor dominan yang berkaitan dengan pasal pada kontrak konstruksi APBD. Analisis kualitatif dilakukan dengan display data dan triangulasi data untuk membandingkan temuan dengan FIDIC Red Book tahun 1999. Berdasarkan hasil analisis kuantitatif ditemukan bahwa faktor paling dominan adalah ketersediaan tenaga kerja. Diatur pada pada kontrak konstruksi APBD di pasal 64. Personil dan/atau peralatan penyedia. Berdasarkan hasil analisis kualitatif dapat disimpulkan bahwa pada FIDIC Red Book 1999, pasalpasal tersebut diatur lebih rinci dan lebih jelas mengenai hak dan kewajiban serta tanggung jawab setiap pihak sehingga dapat meminimalisir terjadinya misinterpretasi terhadap pasal-pasal tersebut.
\end{abstract}

Kata Kunci : Kontrak Konstruksi APBD, Hak dan Kewajiban, FIDIC Red Book 1999, Klaim, Sengketa.

Abstract : Today's construction industry has become very complex and high-risk, so that a good legal-based working relationship is needed. In Indonesia. There have been many cases of construction claims and disputes due to differences in interpretation regarding the clauses in the construction contract and lack of understanding substance of the construction contract. Each construction project in the region uses their own $A P B D$, and most of them are taylor made contracts, which may raise the difference in interpretation as a causal factor of claim and dispute. the purpose of the study are to find the "red clause", which are expected to be use as the basic of the solution on priority the contract in the future in north halmahera district. This research is a mixed method research, beginning with a literature review. Expert tests were carried out using the Delphi Technique. The questionnaire was compiled based on the study of literature on journals, books and previous research. The questionnaire used a Likert scale of 6. The factor analysis was carried out using SPSS 23.0 to find the dominant factor related to the article in the APBD construction contract. Qualitative analysis is performed by comparity the clauses with the 1999's fidic red book. Based on the results of quantitative analysis it is found that the most dominant factor is labor availability. Regulated in the APBD 
construction contract in article 64. Personnel and / or equipment providers, from the results of qualitative analysis, it can be concluded that in the 1999 FIDIC Red Book, the clauses are stipulated cleary the division of right and obligation of each party so as to minimize the misinterpretation of these clauses.

Keywords: APBD Construction Contracts, Rights and Obligations, FIDIC Red Book 1999, Claims, Disputes.

\section{Pendahuluan}

Industri konstruksi merupakan salah satu faktor yang mempengaruhi pertumbuhan ekonomi yang berdampak pada ketersediaan lapangan kerja serta kemajuan suatu negara maupun daerah. Industri konstruksi merupakan segala kegiatan atau usaha yang berkaitan dengan penyiapan lahan, proses konstruksi, perubahan, perbaikan terhadap bangunan, struktur, dan fasilitas sarana prasarana lainnya. Industri konstruksi saat ini telah menjadi sangat kompleks dan berisiko tinggi, Sehingga melibatkan berbagai macam pihak dalam setiap tahapan konstruksi dimulai dari pra konstruksi, pelaksanaan konstruksi sampai dengan pasca konstruksi. Oleh sebab itu kegiatan konstruksi diperlukan adanya ikatan kerja yang baik antara penyedia jasa maupun pengguna jasa yang berdasar hukum dalam suatu perjanjian kontrak konstruksi. Di Indonesia sendiri sudah ada beberapa peraturan maupun undangundang yang mengatur tentang kontrak konstruksi dimana mengacu pada UndangUndang Jasa Konstruksi No.18 tahun 1999, Peraturan Pemerintah No.29 tahun 2000, Peraturan Presiden No.54 Tahun 2010, Peraturan Pemerintah No. 70 tahun 2012. Sedangkan untuk jenis-jenis model kontrak internasional yang biasa dipakai adalah FIDIC (Federation Internationale des Ingenieurs Counsels), JCT Uoin Contract Tribunals) atau AIA (American Institute of Architects). FIDIC memiliki beberapa jenis kontrak yang dikenal yang dipakai untuk proyek konstruksi di antaranya; Condition of contract for Construction yang dikenal dengan "Red book", Condition of contract for Plant and Design-Build yang dikenal "Yellow Book", Condition of contract for Engineering Purchase Construction yang dikenal "Silver Book", " Short Form of Contract yang lebih dikenal "Green book". Di Indonesia sendiri terjadi banyak kasus klaim dan sengketa konstruksi hal ini diakibatkan karena adanya perbedaan prespektif antara pihakpihak yang terlibat dalam proyek konstruksi mengenai pasal-pasal dalam kontrak konstruksi serta kurangnya pemahaman tentang kontrak konstruksi tersebut.

Pada dasarnya setiap daerah telah mendapatkan kewenangan untuk mengembangkan daerah masing-masing yang tertuang pada peraturan otonomi daerah yang diatur sejak tahun 1999 pada undang-undang No. 22 tahun 1999 tentang pemerintahan daerah, undang-undang tersebut mengalami beberapa kali perubahan, seiring dengan berjalannya perkembangan keadaan. Ini merupakan kesempatan untuk pemerintah daerah dalam melakukan pengembangan daerah dengan bebas dan sesuai dengan kebutuhan pembangunan daerah masing-masing, sehingga setiap daerah dapat menentukan peraturan maupun pembangunan di daerah sesuai dengan kebutuhan. Dalam rangka mengembangkan suatu daerah pembangunan sarana maupun prasarana merupakan sesuatu yang penting dalam upaya mengembangkan dan memajukan daerah tersebut. Sehingga setiap proyekproyek konstruksi di daerah menggunakan dana APBD pada umumnya setiap daerah 
membuat kontrak konstruksi sendiri sesuai dengan kebutuhan proyek konstruksi di daerah tersebut, sehingga setiap kontrak berbeda-beda dimana hal ini dapat mengakibatkan ataupun berpotensi terjadinya klaim dan sengketa konstruksi antara pengguna jasa yaitu pemerintah daerah dan penyedia jasa yaitu kontraktor konstruksi maupun konsultan konstruksi. Awal mula permasalahan terjadinya klaim dan sengketa konstruksi di Indonesia diakibatkan dari perbedaan prespektif maupun kurangnya pemahaman terhadap pasal-pasal dalam kontrak konstruksi tersebut. Dan juga pada kontrak konstruksi di proyek-proyek daerah yang menggunakan dana APBD dimana setiap kontrak yang dibuat berbeda dan dibuat sendiri oleh daerah seusai dengan kebutuhannya sehingga hal tersebut dapat berpotensi terjadinya klaim maupun sengketa, sehingga perlu adanya penelitian tentang pasal-pasal apa saja yang dominan berpotensi terjadinya klaim dan sengketa pada kontrak konstruksi APBD kemudian dibandingkan dengan model kontrak internasional yaitu Fidic Red Book 1999. Rumusan masalah dalam penelitian ini adalah : 1 J Pasal-pasal apa saja yang dominan berpotensi terjadinya klaim dan sengketa pada proyek APBD ; dan 2 ) Upaya untuk mengurangi masalah dengan mengacu pada Fidic Red Book Tahun 1999? Manfaat dari penelitian ini diharapkan dapat memberikan informasi untuk pengembangan kontrak konstruksi di kabupaten Halmahera Utara provinsi Maluku Utara baik bagi penyedia jasa maupun pengguna jasa dalam melakukan kegiatan konstruksi agar kedepannya konflik, klaim, maupun sengketa konstruksi dapat diminimalisasi.

\section{UU Nomor 18 Tahun 1999 Tentang Jasa Konstruksi}

Semua kegiatan dalam bidang jasa konstruksi di Indonesia diatur oleh UndangUndang Nomor 18 tahun 1999 tentang Jasa Konstruksi. Pada Bab II Azas dan Tujuan, Pasal 3 dinyatakan bahwa pengaturan jasa konstruksi di Indonesia bertujuan untuk:

a) Memberikan arah pertumbuhan dan perkembangan jasa konstruksi untuk mewujudkan struktur usaha yang kokoh, andal, berdaya saing tinggi, dan hasil pekerjaan konstruksi yang berkualitas.

b) Mewujudkan tertib penyelenggaraan pekerjaan konstruksi yang menjamin keseteraan kedudukan antara pengguna jasa dan penyedia jasa dalam hak dan kewajiban, serta meningkatkan kepatuhan pada ketentuan peraturan perundang-undangan yang berlaku.

c) Mewujudkan peningkatan peran serta masyarakat di bidang jasa konstruksi.

Tujuan di atas dijabarkan menjadi lima tujuan pokok dari Lembaga Pengembangan Jasa Konstruksi, yaitu:

1. Mewujudkan struktur usaha yang kokoh, andal, dan berdaya saing tinggi

2. Mewujudkan hasil pekerjaan konstruksi yang berkualitas

3. Mewujudkan tertib penyelenggaraan pekerjaan konstruksi yang menjamin kesetaraan kedudukan antara pengguna jasa dan penyedia jasa dalam hak dan kewajiban

4. Meningkatkan kepatuhan pada ketentuan peraturan perundangundangan yang berlaku

5. Meningkatkan peran serta masyarakat di bidang jasa konstruksi.

Dari kelima butir di atas, dapat dilihat bahwa "mewujudkan kesetaraan dalam hal dan kewajiban" merupakan suatu hal yang terkait erat dengan perjanjian terkait 
pekerjaan konstruksi, oleh karena itu pembahasan selanjutnya yang dibatasi pada bagaimana selanjutnya butir tersebut untuk mencapai tujuan pengaturan jasa konstruksi yang adil dan berimbang, dan tidak lagi seperti masa lalu. Mengutip yang dikatakan oleh Justice of Singapore's Supreme Court pada pidato pembukaan Annual Confrence Dispute Resolution Board Foundation (DBRF) di Singapura, Loh (2014) ". We must also remember in those days it was common place to have employers squeezing main contractor, main contractors squeezing subcontractor and suppliers and so on down time"

Kesetaraan dalam hak dan kewajiban dapat tercapai apabila kedua belah pihak yaitu pengguna jasa dan penyedia jasa memiliki itikad baik, yang merupakan dasar dari suatu perjanjian. Guna menunjang suatu perjanjian yang dilandasi itikad baik, diperlukan suatu upaya perbaikan sistem, dalam hal ini adalah penggunaan suatu kontrak yang adil dan berimbang (fair and balance), tidak berat sebelah. Artinya, sebagai titik awal upaya ke arah kesetaraan diperlukan penciptaan sistem yang mendukung, dalam hal ini suatu persyaratan umum kontrak (general condition of contract) yang adil dan berimbang.

Pada saat ini di Indonesia, untuk setiap proyek konstruksi dari pengguna jasa yang berbeda biasanya disiapkan suatu persyaratan umum kontrak yang berbeda pula, bahkan dalam suatu institusi yang sama tidak jarang ditemui penggunaan persyaratan umum kontrak dibuat khusus (tailor made) untuk setiap kontrak oleh penyedia jasa konsultan yang kebetulan berbeda. Kejadian ini sebenarnya bertentangan dengan pasal yang dinyatakan bahwa kesetaraan kedudukan antara pengguna jasa dan penyedia jasa, harus dapat diwujudkan. Kontrak konstruksi, dalam hal ini persyaratan umum kontrak yang adil dan berimbang (fair and balanced condition of contract) merupakan salah satu hal yang harus dikembangkan karena jika hal ini tidak dilakukan, maka semua tujuan pembinaan di bidang jasa konstruksi di Indonesia dapat dikatakan tidak berhasil.

\section{Kontrak}

Definisi kontrak menurut pasal 1313 KUHP adalah suatu perbuatan dengan mana satu orang atau lebih mengikatkan dirinya terhadap satu orang lain atau lebih. Definisi menurut UUJK No.18 Tahun 1999 pasal 1 ayat 5 Kontrak Kerja Konstruksi adalah keseluruhan dokumen yang mengatur hubungan hukum antara pengguna jasa dan penyedia jasa dalam penyelenggaraan pekerjaan konstruksi.

Betapa pentingnya suatu kontrak berupa suatu perjanjian yang tertulis, adalah seperti yang dikatakan Lord Wensleydale pada tahun 1861, yang dikutip oleh John Adrianaanse pada Construction Contract Law (2010) "The question is not what the parties to a deed or other document may have intended to do by entering into that deed, but what is the meaning of the words used in that deed: a most important distinction in all cases of construction and disregard of which often leads to errorneous conclusions".

\section{Kontrak Konstruksi}

Garner mendefiniskan kontrak konstruksi sebagai "A contract setting forth the specification for a building project's construction". Yang artinya adalah kontrak konstruksi adalah suatu kontrak yang memuat spesifikasi untuk suatu pembangungan proyek konstruksi. Adriaanse (2010) menyatakan " $A$ variety of factors makes a construction contract different from most other types of contract." Beraneka ragam faktor menjadikan suatu 
kontrak konstruksi berbeda dari kebanyakan kontrak lain. Ini meliputi lamanya proyek, kompleksitas, ukuran dan kenyataan bhawa harga yang disepakati serta jumlah pekerjaan yang harus dikerjakan dapat berubah seiring dengan berlangsungnya kegiatan.

Menurut Undang-Undang No. 2 Tahun 2017 Pasal 1 (8) menyatakan "Kontrak kerja konstruksi adalah keseluruhan dokumen kontrak yang mengatur hubungan hukum antara Pengguna Jasa dan Penyedia Jasa dalam penyelenggaraan Jasa Konstruksi". Lord Diplock (1974) (dikutip oleh John Adriaanse 2010): "an entire contract for the sale of goods and work and labour for a the work done. Decisions have to be made from time about such essentials matters as the making of variation orders, the expenditure of provisional and prime cost sums and extension of time for the carrying out of the work under the contract". Suatu kontrak menyeluruh untuk penjualan barang, pekerjaan dan tenaga kerja dengan suatu harga lumpsum yang dapat dibayarkan dalam beberapa tahapan setelah barang diserahkan dan pekerjaan selesai dilaksanakan.

Hardjomuljadi (2014: 13-14) menyatakan "Suatu kontrak konstruksi tidak dapat ditangani dengan pemahaman yang sama dengan kontrak-kontrak lainnya, karena kontrak konstruksi adalah adalah suatu kontrak yang bersifat sangat dinamis, memperjanjikan suatu barang yang belum ada dan masih memerlukan suatu proses menjadi bentuk yang diperjanjikan, sehingga harga kontrak akan selalu berubah dari waktu ke waktu, karena adanya penyesuaian-penyesuaian volume ataupun perubahan metode pelaksanaan, baik yang diperintahkan oleh pengguna jasa melalui perintah perubahan (VO/Variation Order) maupun yang tidak diperintahkan tetapi harus dikerjakan untuk penyelesaian proyek (CCO/Constructive Change Order). Perbedaan lain dengan kontrak pengadaan barang lainnya, adalah karena kontrak konstruksi memperjanjikan sesuatu yang belum ada, yang harus diselesaikan oleh kontraktor dengan imbalan pembayaran untuk setiap pekerjaan yang dilakukan oleh kontraktor sejauh kualitas dan kuantitasnya sesuai dengan spesifikasi yang disepakati dalam kontrak".

\section{Model Kontrak Konstruksi di Indonesia}

Kontrak konstruksi disepakati sebagai hasil dari proses penawaran dan negosiasi antara pengguna jasa dan penyedia jasa. Formalisasi kontrak dilakukan melalui sesuatu dokumen tertulis yang menjelaskan hak dan kewajiban masing-masing pihak yang terikat di dalamnya. Hingga pertengahan tahun 1999, Indonesia belum memiliki peraturan perundang-undangan yang baku mengenai Jasa Konstruksi. UU No.18/1999 tentang Jasa Konstruksi baru di undangkan pada tahun 1999 dan baru mulai diberlakukan pada tahun 2000 dengan demikian terdapat banyak sekali model kontrak konstruksi di Indonesia namun, secara umum model kontrak-kontrakan tersebut dapat dikelompokkan menjadi 3 golongan yaitu:

1. Versi pemerintah. Biasanya masingmasing Kementerian memiliki suatu "standar" sendiri. Standar yang biasa dipakai adalah Standar Kementerian Pekerjaan Umum. Bahkan Pekerjaan Umum sendiri memiliki lebih dari satu standar karena masing-masing Direktorat Jendral memiliki standarnya masing-masing.

2. Versi Swasta Nasional. Versi ini beraneka ragam sesuai selera pengguna jasa. Terkadang mengutip standar Kementrian atau bagi yang sudah lebih 
maju mengutip (sebagian) sistim kontrak luar negeri seperti FIDIC, JCT atau AIA. Namun karena diadopsi secara sebagian tersebut, maka wajah kontrak versi ini menjadi tidak jelas dan sangat rawan sengekta.

3. Versi Swasta Asing. Umumnya digunakan oleh para pengguna jasa/pemilik proyek asing yang mengadopsi standar kontrak FIDIC, JCT atau AIA.

\section{Federation Inernationale DesIngenierus Counsels (FIDIC)}

FIDIC adalah singkatan dari Federation Internationale DesIngenieurs Counsels atau dalam bahasa Inggris disebut International Federation of Consultant Engineers atau bila diterjemahkan ke dalam bahasa Indonesia adalah Federasi Internasional Konsultan Teknik. Tujuan pembentukan dari federasi ini adalah untuk memajukan secara umum kepentingan-kepentingan profesional dari anggota asosiasi dan menyebarkan informasi atau kepentingannya kepada anggota-anggota dari kumpulan asosiasi nasional. Hal-hal yang diatur dalam persyaratan-persyaratan umum FIDIC adalah sebagai berikut:

1. Ketentuan Umum

2. Pengguna Jasa

3. Enjinir

4. Kontraktor

5. SubKontraktor yang dinominasikan

6. Staf dan Tenaga Kerja

7. Instalasi Mesin, Bahan dan Pengerjaan

8. Tanggal Mulai Pekerjaan, Keterlambatan dan Penghentian

9. Pengujian pada Penyelesaian

10. Serah Terima Kepada Pengguna Jasa

11. Tanggung Jawab atas Cacat Mutu

12. Pengukuran dan Evaluasi

13. Variasi dan Penyesuaian

14. Harga Kontrak dan Pembayaran
15. Pemutusan oleh Pengguna Jasa

16. Penghentian dan Pemutusan oleh Kontraktor

17. Risiko dan Tanggung Jawab

18. Asuransi

19. Keadaan Kahar

20. Klaim, Sengketa dan Arbitrase

Dari hal-hal yang diatur dalam FIDIC conditions of contract, terlihat adanya pasalpasal yang mengatur tentang tuntutan dan perselisihan. Hal itu membuktikan bahwa FIDIC conditions of contract dibuat relatif seimbang antara kepentingan pengguna jasa, konsultan, maupun penyedia jasa sehingga tidak merugikan atau menguntungkan salah satu pihak yang justru merupakan kelemahan yang ada pada kebanyakan conditions of contract di Indonesia sekarang ini.

\section{FIDIC General Conditions of Contract}

FIDIC General Conditions of Contract merupakan salah satu bentuk standar persyaratan umum kontrak (general conditions of contract) yang banyak digunakan dalam proyek konstruksi internasional sejak tahun 1945. Menurut Hardjomuljadi, dkk. (2006) FIDIC CC saat ini merupakan General Conditions of Contract yang direkomendasikan penggunaannya untuk kontrak-kontrak internasional yang didanai oleh IBRD (Bank Dunia, the International Bank of Reconstruction and Development), ADB (Asian Development Bank), JBIC Uapan Bank ForInternational Cooperation) dsb. Alasan institusi pemberi pinjaman seperti World Bank, ADB, JBIC, dan yang lain untuk merekomendasikan penggunaan FIDIC Conditions of Contract adalah karena adanya pembagian risiko yang sangat jelas dalam FIDIC Conditions of Contract sehingga dianggap sangat adil sebagaimana dinyatakan oleh MortimerHawkins “... the principal obligation of the 
contractor is to execute and complete the works in strict accordance with the terms and conditions of the contract, but the employer is also required to carry certain risk under the contract" (Mortimer-Hawkins, 1993 dalam Hardjomuljadi, 2014: 24). Penggunaan suatu standar persyaratan umum kontrak tidak hanya untuk menjaga terlaksananya perjanjian kontrak dengan baik tetapi juga untuk mengurangi ketidakpastian (uncertainties) sehingga harga penawaran dapat dibuat lebih rendah, karena risiko bagi Kontraktor yang lebih rendah. Di samping itu, penggunaan suatu standar bagi Pengguna Jasa akan mempermudah pengawasan pelaksanaan konstruksi dengan berbekal pada pengalaman yang diperoleh dari proyek sejenis yang sudah pernah dilaksanakan sebelumnya.

\section{Latar Belakang dan Sejarah FIDIC Conditions of Contract}

Mengutip dari Hardjomuljadi, dkk. (2006: 19-20), Hardomuljadi memberikan penjelasan singkat terkait latar belakang dan sejarah FIDIC CC. Sebelum pertengahan abad 17, masalah yang timbul dalam proyek konstruksi internasional umumnya disebabkan oleh pertentangan kekuatan hukum (kontraktual) antara pihak yang dijajah dengan pihak yang menjajah dan biasanya akan berakhir dengan menangnya kekuatan hukum pihak yang menjajah. Akan tetapi, setelah pertengahan abad ke 17, pertentangan kekuatan hukum mengalami perubahan bentuk karena pengguna common law, dalam hal ini terutama Inggris, mulai menguasai pengguna civil law seperti yang banyak terjadi di Asia, Afrika Utara dan Amerika Utara dan dalam perkembangan selanjutnya common law lebih berpengaruh ketimbang civil law. Berdasarkan arsip yang tersimpan pada Chartered Institute of Arbitration di London, tidak banyak proyek konstruksi internasional berskala besar hingga tahun 1900 karena adanya revolusi industri. Amerika Serikat merupakan negara pertama di dunia yang mengembangkan kegiatan konstruksinya ke pasar konstruksi internasional terutama ke Mexico dan negara-negara di Amerika Serikat di mana berlaku sistem hukum sipil yang dibat oleh Spanyol, ini terjadi pada awal tahun 1900an.

Selama masa ini, kontraktor Amerika Serikat pertama kali menghadapi keberadaan Doktrin Calvo di setiap negara Amerika Latin, dimana dalam aspek hukum common law tidak dapat menunjukkan keperkasaannya terhadap hukum sipil (hukum Latin). Hingga awal pecahnya Perang Dunia II, Amerika Serikat menutup dirinya tidak hanya dalam hubungan diplomatik tetapi juga dalam hubungan komersial dengan negara-negara lain. Setelah berakhirnya Perang Dunia II (19401945), untuk dapat membangun kembali Eropa sesegera mungkin, Amerika Serikat menyediakan Rencana Marshall (Marshall Plan). Untuk menghindari pertentangan hukum atau kontraktual seperti yang dialami Amerika Serikat pada awal tahun 1900-an di Mexico dan negara-negara Amerika Latin lainnya dan agar Rencana Marshall dpat terlaksana secara efektif tanpa merugikan pihak Kontraktor asing, maka untuk pertama kalinya, pada bulan Desember 1945 diberlakukan "Standard Form of the General Condition of Contract" yang disiapkan oleh FIDIC (Federation Internationale des Ingenieur Conseils) dan pembentukan ICC (International Chamber of Commerce) untuk menyelesaikan sengketa dagang (komersial) di dunia. 


\section{FIDIC Conditions of Contract for Construction 1999}

Red Book atau FIDIC Conditions of Contract for Construction 1999 memberikan ketentuan kontrak untuk pekerjaan konstruksi dimana hampir keseluruhan desain disiapkan oleh pengguna jasa. atau konsultan perencana yang ditunjuk oleh pengguna jasa. Red Book tidak cocok digunakan untuk pekerjaan yang mayoritas pekerjaannya dirancang oleh kontraktor. Dalam pelaksanaan Red Book, administrasi dan pengawasan proyek dilakukan oleh seorang enjinir yang dipekerjakan oleh pengguna jasa. Enjinir di samping mengawasi pelaksanaan pekerjaan sesuai dengan spesifikasi yang disepakati dalam kontrak, juga melaksanakan administrasi kontrak, monitoring pekerjaan konstruksi di lapangan, dan menyiapkan berita acara untuk pembayaran berdasarkan hasil pengukuran atas pekerjaan yang telah dilaksanakan sesuai kontrak dan dibayarkan sesuai harga satuan saat tender, daftar harga satuan dan/atau lump sum (Hardjomuljadi, 2014). Ketika enjinir dibutuhkan pendapatnya untuk menentukan suatu masalah atau menyelesaikan suatu klaim, ia diharuskan untuk berkonsultasi dengan masing-masing pihak untuk mencoba dan mencapai kesepakatan. Apabila kesepakatan tidak dapat dicapai, maka enjinir harus membuat keputusan yang adil dengan mempertimbangkan semua keadaan yang relevan. Apabila pendapat enjinir tidak disetujui oleh salah satu pihak, maka perselisihan akan dirujuk ke dewan sengketa untuk memperoleh suatu keputusan. Adapun isi dari Red Book terdiri dari General Conditions, Guidance for the Preparation of the Particular Conditions, Forms of Tender and Contract Agreement, dan Dispute Adjudication Agreement.

\section{Klaim Konstruksi (Construction Claim)}

Garner (2004) mendefinisikan klaim adalah "Suatu tuntutan atas uang, kepemilikan atau suatu pemulihan hukum yang berhak didapatkan seseorang". Hardjomuljadi, dkk. (2006) menyatakan "Klaim adalah suatu tindakan seseorang untuk meminta sesuatu dimana hak seseorang tersebut telah hilang sebelumnya, karena yang bersangkutan beranggapan memiliki hak untuk mendapatkannya kembali, sedangkan pengguna jasa akan menggunakan haknya sesuai dengan apa yang dinyatakan dalam conditions of contract, bukan hanya berkutat pada upaya menolak klaim yang diajukan kontraktor, bagaimanapun caranya". Hansen (2018) menyatakan "Klaim konstruksi terjadi manakala salah satu pihak yang terlibat dalam kontrak konstruksi meyakini bahwa pihak lain telah lalai atau belum memenuhi kewajibannya sebagaimana yang tertera dalam kontrak". Tidak dipenuhinya kewajiban sesuai kontrak, dapat disebabkan adanya pelanggaran yang disadari oleh pihak yang melanggar atau dapat juga disebabkan karena masing-masing pihak yang terikat kontrak konstruksi tidak memahami dengan baik pengertian dari setiap kata dalam kontrak atau terjadinya different interpretation of contract clauses (Hardjomuljadi, 2015: 12).

Hardjomuljadi, dkk. (2006: 64-65) menyatakan bahwa terdapat beberapa jenis klaim konstruksi yang memiliki definisi yang jelas sesuai dengan terminologi kontraktualnya, yaitu:

1. Contractual Claims. Contractual Claims adalah klaim konstruksi dimana Kontraktor secara spesifik/nyata memang berhak dibayar dengan cara reimbursement dan secara jelas mempunyai dasar legal yang tercantum di dalam kontrak seperti misalnya klaim 
konstruksi yang disebabkan oleh SubKlausula 4.12 tentang Unforeseeable Physical Conditions.

2. Non-Contractual Claims. NonContractual Claims adalah klaim konstruksi yang cara penyelesaiannya secara spesifik tidak ditetapkan dalam kontrak, seperti misalnya klaim pekerjaan konstruksi yang disebabkan oleh perubahan nilai tukar mata uang asing yang digunakan dalam proyek. Sinonim dari terminologi ini adalah " $E x$ gratia Claims" yang berarti bahwa klaim konstruksi ini dapat diselesaikan semata-mata karena kebaikan hati dari pengguna jasa.

3. Construction claims yang "claimable" dan "reimbursable". Adalah sangat menarik bahwa kata "claimable" tidak selalu akan berarti "reimbursable". Khusus untuk klaim konstruksi yang merupakan contractual claims, pastilah berarti bahwa klaim tersebut "claimable" dan "reimbursable".

4. Construction claims yang "claimable" tetapi "non-reimbursable". Biasanya klaim konstruksi yang merupakan noncontractual claim disebut sebagai klaim yang berada pada posisi "claimable" tetapi "non-reimbursable".

Hardjomuljadi (2016: 13-17) juga mengatakan bahwa dalam pelaksanaan pekerjaan konstruksi, klaim yang diajukan oleh kontraktor dapat dikategorikan menjadi 3 (tiga) kelompok besar yaitu Klaim konstruksi akibat perubahan waktu pelaksanaan, klaim konstruksi akibat perintah perubahan (variation order), dan klaim konstruksi akibat unforeseeable physical conditions.

\section{Sengketa}

Sengketa atau dispute menurut Black's Law Dictionary adalah "a conflict or controversy".
Sengketa menurut Kamus Besar Bahasa Indonesia adalah "pertentangan atau konflik, konflik berarti adanya oposisi atau pertentangan antara orang-orang, kelompok-kelompok, atau organisasiorganisasi terhadap satu objek permasalahan". Hardjomuljadi (2016: 18) menyatakan "sengketa merupakan suatu keadaan yang menempatkan suatu pihak yang ingin memaksakan kehendaknya kepada pihak lain yang menentang kehendak tersebut dan mengadakan perlawanan". Menurut Rahmadi (2010: 1), "konflik atau sengketa merupakan situasi dan kondisi dimana orang-orang saling mengalami perselisihan yang bersifat faktual maupun perselisihan-perselisihan yang ada pada persepsi mereka saja". Masruchiyah (2018: 27) mengatakan bahwa "dalam konteks hukum kontrak, yang dimaksud dengan sengketa adalah perselisihan yang terjadi antara para pihak karena adanya pelanggaran terhadap kesepakatan yang telah dituangkan dalam suatu kontrak, baik sebagian maupun keseluruhan". Hardjomuljadi (2016: 18) menyatakan sengketa dianggap telah terjadi, setelah melalui proses sebagai berikut:

1. Kontraktor menyampaikan klaim tambahan biaya, perpanjangan waktu atau hal lain,

2. Enjinir/pengguna jasa menolak klaim dengan disertai alasan penolakan, berupa suatu Engineer Determination.

Kontraktor menyatakan tidak sependapat dengan alasan penolakan klaim oleh enjinir/pengguna jasa.

\section{Sebab - Sebab Timbulnya Sengketa}

Rahmadi (2011: 8-10) menyatakan bahwa terdapat beberapa teori tentang sebabsebab timbulnya sengketa yang akan dijabarkan sebagai berikut: 
1. Teori Hubungan Masyarakat. Teori hubungan masyarakat, menitikberatkan adanya ketidakpercayaan dan rivalisasi kelompok dalam masyarakat. Para penganut teori ini memberikan solusisolusi terhadap konflik-konflik yang timbul dengan cara peningkatan komunikasi dan saling pengertian antara kelompok-kelompok yang mengalami konflik, serta pengembangan toleransi agar masyarakat lebih bisa saling menerima keberagaman dalam masyarakat.

2. Teori Negosiasi Prinsip. Teori negosiasi prinsip menjelaskan bahwa konflik terjadi karena adanya perbedaanperbedaan diantara pihak. Para penganjur teori ini berpendapat bahwa agar sebuah konflik dapat diselesaikan, maka pelaku harus mampu memisahkan perasaan pribadinya dengan masalah-masalah dan mampu melakukan negosiasi berdasarkan kepentingan dan bukan pada posisi yang sudah tetap.

3. Teori Identitas. Teori ini menjelaskan bahwa konflik terjadi karena sekelompok orang merasa identitasnya terancam oleh pihak lain. Penganut teori identitas mengusulkan penyelesaian konflik karena identitas yang terancam dilakukan melalui fasilitasi lokakarya dan dialog antara wakil-wakil kelompok yang mengalami konflik dengan tujuan mengidentifikasi ancaman-ancaman dan kekhawatiran yang mereka rasakan serta membangun empati dan rekonsiliasi. Tujuan akhirnya adalah pencapaian kesepakatan bersama yang mengakui identitas pokok semua pihak.

4. Teori Kesalahpahaman Antar Budaya. Teori kesalahpahaman antar budaya menjelaskan bahwa konflik terjadi karena ketidakcocokan dalam berkomunikasi diantara orang-orang dari latar belakang budaya yang berbeda. Untuk itu diperlukan dialog antara orang-orang yang mengalami konflik guna mengenal dan memahami budaya masyarakat lainnya, mengurangi stereotype yang mereka miliki terhadap pihak lain.

5. Teori Transformasi. Teori ini menjelaskan bahwa konflik dapat terjadi karena adanya masalah-masalah ketidaksetaraan dan ketidakadilan serta kesenjangan yang terwujud dalam berbagai aspek kehidupan masyarakat baik sosial, ekonomi maupun politik. Penganut teori ini berpendapat bahwa penyelesaian konflik dapat dilakukan melalui beberapa upaya seperti perubahan struktur dan kerangka kerja yang menyebabkan ketidaksetaraan, peningkatan hubungan, dan sikap jangka panjang para pihak yang mengalami konflik, serta pengembangan proses-proses dan sistem untuk mewujudkan pemberdayaan, keadilan, rekonsiliasi dan pengakuan keberadaan masingmasing.

6. Teori Kebutuhan atau Kepentingan Manusia. Pada intinya, teori ini mengungkapkan bahwa konflik dapat terjadi karena kebutuhan atau kepentingan manusia tidak dapat terpenuhi/terhalangi atau merasa dihalangi oleh orang/pihak lain. Kebutuhan dan kepentingan manusia dapat dibedakan menjadi tiga jenis yaitu substantif, prosedural, dan psikologis. Kepentingan substantif (substantive) berkaitan dengan kebutuhan manusia yang berhubungan dengan kebendaan seperti uang, sandang, pangan, papan/rumah, dan kekayaan. 
Kepentingan prosedural (procedural) berkaitan dengan tata dalam pergaulan masyarakat, sedangkan kepentingan psikologis (psychological) berhubungan dengan non-materil atau bukan kebendaan seperti penghargaan dan empati.

Masruchiyah (2018: 34) mengatakan bahwa sengketa kontrak kerja konstruksi dapat timbul antara lain karena klaim yang tidak dilayani misalnya keterlambatan pembayaran, keterlambatan penyelesaian pekerjaan, perbedaan penafsiran dokumen kontrak, ketidakmampuan baik teknis maupun manajerial dari para pihak. Selain itu sengketa konstruksi dapat pula terjadi apabila Pengguna Jasa ternyata tidak melaksanakan tugas-tugas pengelolaan dengan baik dan mungkin tidak memiliki dukungan dana yang cukup dan/atau adanya kegagalan bangunan yaitu suatu keadaan keruntuhan bangunan dan/atau tidak berfungsinya bangunan setelah penyerahan hasil akhir Jasa Konstruksi.

\section{Jenis Penelitian}

Penelitian ini adalah penelitian dasar (Fundamental Research). Berdasarkan teknik pengumpulan data, penelitian ini adala mixed method. Mixed method adalah jenis penelitian yang menggabungkan penelitian kuantitatif dan kualitatif (Neuman, 2014).

\section{Data dan Variabel}

Data primer dalam penelitian ini di dapat melalui penyebaran kuesioner kepada pihak Kontraktor dan pihak Pemilik proyek. Isi dari kuesioner merupakan suatu daftar yang berisi variabel-variabel tentang pasal-pasal yang berpotensi menimbulkan klaim dan sengketa pada kontrak konstruksi APBD kabupaten Halmahera Utara provinsi Maluku Utara.

Data sekunder yang digunakan dalam penelitian ini adalah literatur yang termuat dalam buku-buku, jurnal dan berbagai media yang berhubungan dengan topik penelitian ini. Data sekunder juga dibutuhkan sebagai landasan teori dan penentuan variabel penelitian yang digunakan dalam kuesioner. Variabel penelitian didapatkan dari studi literatur terhadap faktor-faktor penyebab klaim dan sengketa konstruksi dalam kontrak konstruksi proyek APBD.

\section{Instrumen Penelitian}

Instrumen dalam penelitian ini adalah kuesioner dengan 23 butir pernyataan. Penyebaran kuesioner dilakukan dengan beberapa cara seperti penyerahan kuesioner secara pribadi dan menggunakan Google Form yang link-nya dikirim melalui email atau whatsapp.

\section{Teknik Pengumpulan data}

Teknik pengumpulan data kuantitatif yang digunakan dalam penelitian ini adalah membagikan kuesioner (angket) kepada pihak pengguna jasa, konsultan, dan kontraktor. Kuesioner yang digunakan dalam penelitian ini adalah kuesioner tertutup, yaitu kuesioner yang sudah disediakan jawabannya, sehingga responden tinggal memilih dan menjawab secara langsung. Kuesioner ini terdiri dari 23 pernyataan tertulis yang digunakan untuk mendapatkan informasi dari responden.

\section{Analisis Faktor}

Analisis faktor adalah suatu teknik analisis yang digunakan untuk memahami yang mendasari faktor-faktor atau regularitas 
suatu gejala. Tujuan utama teknik ini adalah untuk membuat ringkasan informasi yang dikandung dalam sejumlah besar variabel ke dalam suatu kelompok faktor yang lebih kecil. Secara statistik, tujuan pokok teknik ini ialah untuk menentukan kombinasi linier variabel-variabel yang akan membantu dalam penyelidikan keterkaitan diantara variabel-variabel tersebut. Kegunaan utama analisis faktor adalah untuk melakukan pengurangan data atau dengan kata lain melakukan peringkasan sejumlah variabel menjadi lebih kecil jumlahnya. Pengurangan dilakukan dengan melihat interdependensi beberapa variabel yang dapat dijadikan satu yang disebut faktor, sehingga ditemukan variabel-variabel atau faktor-faktor yang dominan atau penting untuk dianalisa lebih lanjut.

\section{Analisis Data}

Metode analisis data dilakukan setelah data yang didapatkan terkumpul dan merupakan tahapan terakhir pada sebuah penelitian. Menurut Sugiyono (2007) "Metode analisis data sendiri merupakan proses mencari dan menyusun secara sistematis data yang diperoleh dari hasil wawancara, catatan lapangan dan dokumentasi, dengan cara mengorganisasikan data ke dalam kategori, menjabarkan ke dalam unit-unit, melakukan sintesa, menyusun ke dalam pola, memilih mana yang penting dan mana yang akan dipelajari, dan membuat kesimpulan sehingga mudah dipahami oleh peneliti sendiri maupun orang lain". Sehingga dalam melakukan penelitian dibutuhkan metode analisis yang tepat untuk menghasilkan kesimpulan yang sesuai dengan tujuan penelitian.

\section{Analisis Kuantitatif}

Analisis yang lakukan pada penelitian ini dimulai dengan mencari faktor dominan yang menjadi faktor penyebab klaim dan sengketa konstruksi pada kontrak Konstruksi Proyek APBD di kabupaten Halmahera Utara provinsi Maluku Utara. Tahapan-tahapan tersebut dimulai dengan mengumpulkan variabel-variabel dari diskusi dan studi literatur yang relevan dengan topik penelitian ini. Selanjutnya setelah variabel-variabel tersebut disebarkan melalui kuesioner kepada responden yang telah ditentukan, unutuk mendapatkan faktor-faktor dominan yang menjadi penyebab klaim dan sengketa konstruksi pada kontrak konstruksi proyek APBD di kabupaten Halmahera Utara provinsi Maluku Utara. setelah didapatkan faktor-faktor yang dominan kemudian, variabel dominan tersebut disebarkan melalui kuesioner kepada 3 (orang) orang yang di anggap adalah pakar. Tujuan dari kuesioner tahap kedua ini untuk mendapatkan validasi dari orang-orang yang dianggap pakar di bidang kontrak konstruksi.

\section{Analisis Kualitatif}

Tahapan selanjutnya dari penelitian ini adalah melakukan analisis perbandingan antara faktor penyebab klaim dan sengketa konstruksi yang mengacu pada FIDIC Red Book Tahun 1999. Analisis perbandingan ini dilakukan dengan cara membandingkan interpretasi dari klausula-klausula yang mengatur dan memiliki hubungan dengan faktor-faktor dominan penyebab klaim dan sengketa konstruksi pada kontrak konstruksi proyek APBD di kabupaten Halmahera Utara yang telah didapat, terhadap klausula-klausula yang mengatur 
dan memiliki hubungan pada FIDIC Red Book Tahun 1999.

\section{Uji Validitas dan Reliabilitas}

Uji validitas dalam penelitian ini dilakukan terhadap semua butir kuesioner yang digunakan dalam penelitian ini. Setelah dilakukan uji validitas terhadap 23 butir pertanyaan tidak ditemukan variabel yang tidak valid. Hasil uji reliabilitas instrument dapat dilihat pada Tabel 1 dan Tabel 2.

Tabel 1. Faktor dan Kode Kuesioner

\begin{tabular}{|c|l|}
\hline Variabel & \multicolumn{1}{|c|}{ FAKTOR } \\
\hline X1 & Gambar yang belum final \\
\hline X2 & $\begin{array}{l}\text { Keterlambatan ketersediaan lahan kerja / Hak } \\
\text { untuk memasuki lapangan proyek }\end{array}$ \\
\hline X3 & Instruksi dari enjinir \\
\hline X4 & Serah terima sebagian dari pekerjaan \\
\hline X5 & Pengetesan \\
\hline X6 & $\begin{array}{l}\text { Penundaan pengujian pada penyelesaian } \\
\text { pekerjaan / gangguan terhadap pengujian dan } \\
\text { penyelesaian }\end{array}$ \\
\hline X7 & Perubahan lingkup pekerjaan \\
\hline X8 & Keterlambatan pembayaran \\
\hline X9 & Penghentian pekerjaan \\
\hline X10 & Subkontraktor tidak kompeten \\
\hline X11 & Jadwal penundaan \\
\hline X12 & Penundaan pembayaran progres oleh pemilik \\
\hline X13 & Pembayaran pada saat pemutusan kontrak \\
\hline X14 & Perpanjangan waktu penyelesaian pekerjaan \\
\hline X15 & Konsekuiensi keadaan kahar \\
\hline X16 & Masalah lingkungan \\
\hline X17 & Ketersediaan material \\
\hline X18 & Kecelakaan / keselamatan \\
\hline X19 & Ketersediaan Pabrik \& peralatan \\
\hline X20 & Ketersediaan tenaga Kerja \\
\hline X21 & Keterlambatan yang disebabkan oleh kontraktor \\
\hline X22 & Pekerjaan yang rusak / cacat mutu \\
\hline X23 & Perubahan Biaya Bahan dan Tenaga Kerja \\
\hline
\end{tabular}

Tabel 2. Uji Reliabilitas Instrumen

Reliability Statistics

\begin{tabular}{|r|r|}
\hline $\begin{array}{c}\text { Cronbach's } \\
\text { Alpha }\end{array}$ & N of Items \\
\hline .900 & 23 \\
\hline
\end{tabular}

\begin{tabular}{|l|l|}
\hline Kurang dari 0,5 & Tidak dapat Diterima \\
\hline 0,5 hingga 0,6 & Reliabilitas Kurang \\
\hline 0,6 hinggga 0,7 & Reliabilitas Bermasalah \\
\hline 0,7 hingga 0,8 & $\begin{array}{l}\text { Reliabilitas dapat } \\
\text { ditermia }\end{array}$ \\
\hline 0,8 hingga 0,9 & Reliabilitas Baik \\
\hline 0,9 ke atas & Istimewa \\
\hline
\end{tabular}

\section{Deskripsi Responden}

Responden dalam penelitian ini adalah 33 responden yang tersebar dari orang terdiri dari : 1) konsultan sebanyak 1 orang dengan persentase 3,03\%, kontraktor sebanyak 22 orang dengan persentase 66,67 \%, dan pemilik proyek sebanyak 10 orang dengan persentase 30,3 \%. Berdasarkan latar belakang pendidikan S1 sebanyak 25 orang dengan persentase 75,8 \%, S2 sebanyak 5 orang dengan persentase $15,15 \%$, S3 sebanyak 1 orang dengan persentase 3,03\%, dan SMA sebanyak 2 orang dengan persentase $\quad 6,06 \%$ Berdasarkan pengalaman kerja dimana pengalaman kerja $>15$ tahun sebanyak 5 orang dengan persentase $15,15 \%$, dan pengalaman kerja 5-10 tahun sebanyak 28 orang dengan persentase $84,85 \%$.

\section{Analisis Faktor}

Analisis faktor dalam penelitian ini dilakukan terhadap 23 faktor. Analisis faktor dilakukan dengan menggunakan software SPSS 24.0.

Uji analisis faktor dilakukan dengan cara uji KMO MSA (Kaiser-Meyer-Olkin Measure of Sampling Adequacy) menggunakan software SPSS 24.0. Hasil output SPSS uji KMO MSA 
kelompok pertama dapat dilihat pada Tabel 3.

Tabel 3. KMO dan Barlett's Test

\begin{tabular}{|c|c|c|}
\hline \multicolumn{3}{|c|}{ KMO and Bartlett's Test } \\
\hline \multicolumn{2}{|c|}{ Kaiser-Meyer-Olkin Measure of Sampling Adequacy. } & .558 \\
\hline \multirow{3}{*}{$\begin{array}{l}\text { Bartlett's Test of } \\
\text { Sphericity }\end{array}$} & Approx. Chi-Square & 603.178 \\
\hline & df & 253 \\
\hline & Sig. & .000 \\
\hline
\end{tabular}

Berdasarkan Tabel 3. terlihat nilai KMO MSA $=0,558>0,5$ yang berarti analisis faktor dapat dilanjutkan. Proses selanjutnya adalah melihat tabel Anti image Matrices. Hasil output SPSS uji Anti image Matrices kelompok besar dapat dilihat tabel pada Tabel 4.

Tabel 4. Anti Image Matrices

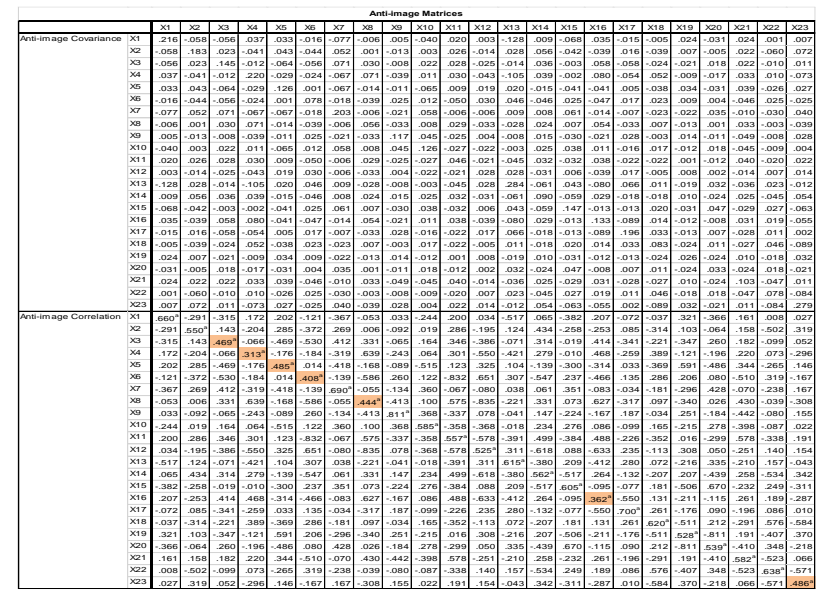

Berdasarkan Tabel 4. Anti-image Matrices, terdapat huruf superscript menunjukkan data yang menjadi tolak ukur valid atau tidaknya fungsi tersebut. Data dianggap valid jika memiliki nilai lebih besar dari 0,5 dan tidak valid jika memiliki nilai kurang dari 0,5. Pada Tabel 4. terlihat hasil dari Antiimage Matrices terdapat beberapa faktor yang tidak valid karena memiliki nilai lebih kecil dari 0,5 yaitu faktor X3, X4, X5, X6, X8, $\mathrm{X} 16$, dan $\mathrm{X} 23$, sehingga perlu dilakukan analisis kembali dengan tidak memasukan faktor-faktor yang tidak valid. Hasil analisis kedua dapat dilihat pada Tabel 5.
Tabel 5. KMO dan Barlett's Test

\begin{tabular}{|c|c|c|}
\hline \multicolumn{3}{|c|}{ KMO and Bartlett's Test } \\
\hline \multicolumn{2}{|c|}{ Kaiser-Meyer-Olkin Measure of Sampling Adequacy. } & .682 \\
\hline \multirow{3}{*}{$\begin{array}{l}\text { Bartlett's Test of } \\
\text { Sphericity }\end{array}$} & Approx. Chi-Square & 372.408 \\
\hline & df & 120 \\
\hline & Sig. & .000 \\
\hline
\end{tabular}

Berdasarkan Tabel 5. terlihat nilai KMO MSA $=0,682>0,5$ lebih besar dari analisis pertama. Dimana syarat telah terpenuhi, yang berarti analisis faktor dapat dilanjutkan. Proses selanjutnya adalah melihat tabel Anti image Matrices. Hasil output SPSS uji Anti image Matrices kelompok besar dapat dilihat tabel pada Tabel 6.

Tabel 6. Anti Image Matrices

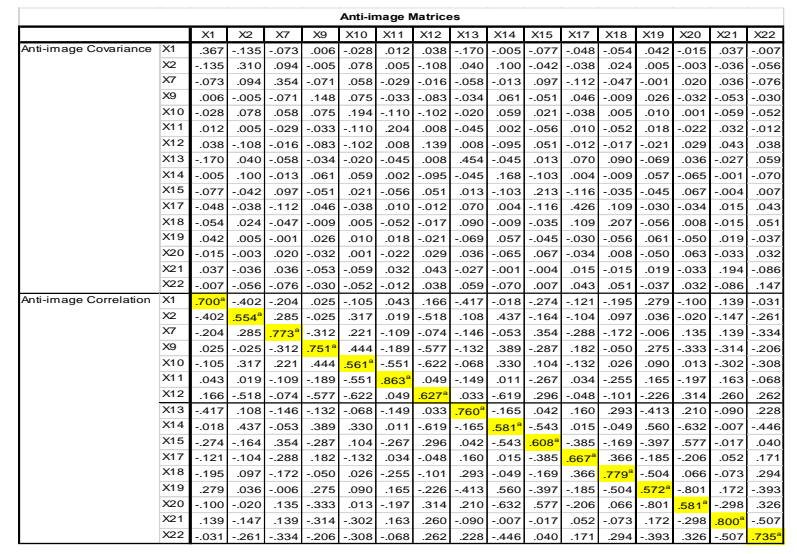

Berdasarkan Tabel 6. Anti-image Matrices kedua yang terdapat huruf superscript menunjukkan data yang menjadi tolak ukur valid atau tidaknya fungsi tersebut. Pada Tabel 6. Terlihat hasil dari Anti Image Matrices dari semua faktor memiliki nilai lebih besar dari 0.5 sehingga semua faktor pada kelompok ini dapat digunakan.

Proses selanjutnya dilakukan dengan cara uji Communalities. Hasil output SPSS uji Communalities kelompok besar dapat dilihat pada Tabel 7. Communalities digunakan untuk mengetahui seberapa besar sebuah variabel dapat menjelaskan faktor. 
Tabel 7. Communalities

\begin{tabular}{|l|c|r|}
\hline \multicolumn{3}{|c}{ Communalities } \\
\hline & Initial & Extraction \\
\hline$\times 1$ & 1.000 & .782 \\
$\times 2$ & 1.000 & .578 \\
$\times 7$ & 1.000 & .457 \\
$\times 9$ & 1.000 & .740 \\
$\times 10$ & 1.000 & .577 \\
$\times 11$ & 1.000 & .726 \\
$\times 12$ & 1.000 & .709 \\
$\times 13$ & 1.000 & .459 \\
$\times 14$ & 1.000 & .540 \\
$\times 15$ & 1.000 & .738 \\
$\times 17$ & 1.000 & .560 \\
$\times 18$ & 1.000 & .695 \\
$\times 19$ & 1.000 & .886 \\
$\times 20$ & 1.000 & .900 \\
$\times 21$ & 1.000 & .681 \\
$\times 22$ & 1.000 & .768 \\
\hline
\end{tabular}

Extraction Method: Principal Component Analysis.

Berdasarkan Tabel 7. Tersebut dapat disimpulkan hal-hal sebagai berikut :

1. Nilai extraction dari variabel X20 yaitu Ketersediaan tenaga kerja $=0,900$. Artinya penyebab klaim dapat diwakili faktor ketersediaan tenaga kerja sebesar $90 \%$;

2. Nilai extraction dari variabel X19 yaitu ketersediaan pabrik \& peralatan = 0,866 . Ini artinya penyebab klaim dapat diwakili faktor ketersediaan pabrik \& peralatan sebesar 86,6\%;

3. Nilai extraction dari variabel X1 yaitu gambar yang belum final $=0,782$. Ini artinya penyebab klaim dapat diwakili faktor gambar yang belum final sebesar $78,2 \%$;

4. Nilai extraction dari variabel X22 yaitu pekerjaan yang rusak / cacat mutu = 0,768 . Ini artinya Penyebab klaim dapat diwakili faktor pekerjaan yang rusak / Cacat mutu sebesar 76,8 \%;

5. Nilai extraction dari variabel X9 yaitu penghentian pekerjaan $=0,740$. Ini artinya penyebab klaim dapat diwakili faktor penghentian pekerjaan sebesar $74 \%$;

6. Nilai extraction dari variabel X15 yaitu konsekuensi keadaan kahar $=0,738$. Ini artinya penyebab klaim dapat diwakili faktor konsekuiensi keadaan kahar sebesar 73,8 \%;

7. Nilai extraction dari variabel X11 yaitu Jadwal penundaan $=0,726$. Ini artinya penyebab klaim dapat diwakili faktor jadwal penundaan sebesar 72,6\%;

8. Nilai extraction dari variabel X12 yaitu penundaan pembayaran progress oleh pemilik $=0,709$. Ini artinya penyebab klaim dapat diwakili faktor penundaan pembayaran progress oleh pemilik sebesar 70,9\%;

9. Nilai extraction dari variabel X18 yaitu kecelakaan / keselamatan $=0,695$. Ini artinya penyebab klaim dapat diwakili faktor kecelakaan / keselamatan sebesar 69,5\%;

10. Nilai extraction dari variabel X21 yaitu keterlambatan yang disebabkan oleh kontraktor $=0,681$. Ini artinya penyebab klaim dapat diwakili faktor keterlambatan yang disebabkan oleh kontraktor sebesar 68,1\%;

11. Nilai extraction dari variabel $\mathrm{X} 2$ yaitu keterlambatan ketersediaan lahan kerja / hak untuk memasuki lapangan proyek $=0,578$. Ini artinya penyebab klaim dapat diwakili faktor keterlambatan ketersediaan lahan kerja / hak untuk memasuki lapangan proyek sebesar $57,8 \%$;

12. Nilai extraction dari variabel $\mathrm{X} 10$ yaitu subkontraktor tidak kompeten $=0,577$. Ini artinya penyebab klaim dapat diwakili faktor subkontraktor tidak kompeten sebesar 57,7 \%;

13. Nilai extraction dari variabel X17 yaitu ketersediaan material $=0,560$. Ini artinya penyebab klaim dapat diwakili 
faktor ketersediaan material sebesar 56 $\%$;

14. Nilai extraction dari variabel X14 yaitu perpanjangan waktu penyelesaian pekerjaan $=0,540$. Ini artinya penyebab klaim dapat diwakili faktor perpanjangan waktu penyelesaian pekerjaan sebesar $54 \%$;

15. Nilai extraction dari variabel X13 yaitu pembayaran pada saat pemutusan kontrak $=0,459$. Ini artinya penyebab klaim dapat diwakili faktor pembayaran pada saat pemutusan kontrak sebesar $45,9 \%$;

16. Nilai extraction dari variabel $\mathrm{X} 7$ yaitu perubahan lingkup pekerjaan $=0,457$. Ini artinya penyebab klaim dapat diwakili faktor perubahan lingkup pekerjaan sebesar 45,7\%;

\section{Analisis Kualitatif}

Tahapan selanjutnya dari penelitian ini adalah melakukan analisis perbandingan antara faktor penyebab klaim yang telah di dapat dari hasil analisis faktor, terhadap literatur FIDIC red Book tahun 1999. Analisis perbandingan ini dilakukan dengan cara membandingkan interpretasi dari klausulaklausula yang mengatur dan memiliki hubungan dengan faktor-faktor dominan penyebab klaim pada Kontrak Konstruksi APBD kabupaten Halmahera Utara Maluku Utara yang telah didapat, terhadap klausulaklausula yang mengatur dan memiliki hubungan pada FIDIC Red Book TAHUN 1999.

Klausula-klasula yang dianggap mengatur dan memiliki hubungan dengan faktorfaktor dominan tersebut dipilih berdasarkan hasil analisis faktor dimana faktor yang paling dominan yang telah di validasi oleh pakar. Dari 10 (sepuluh) faktor dominan yang didapat, dipilih 5 (faktor) dimana terkait klausula-klausula yang mengatur dan memiliki hubungan dengan faktor-faktor dominan tersebut, yang nanti nya akan dibandingkan isi dan interpretasi antara klausula-klasula pada Kontrak Konstruksi APBD kabupaten Halmahera Utara Maluku Utara dengan klausula-klausla pada literatur FIDIC red Book tahun 1999.

Tabel 8. Hasil analisis faktor

\begin{tabular}{|c|c|c|c|}
\hline Variabel & $\begin{array}{c}\text { Faktor-faktor } \\
\text { dominan } \\
\text { berpotensi } \\
\text { klaim dan } \\
\text { sengketa } \\
\end{array}$ & $\begin{array}{c}\text { Kontrak APBD } \\
\text { Halmahera Utara }\end{array}$ & FIDIC Red Book 1999 \\
\hline $\mathrm{X} 20$ & $\begin{array}{l}\text { Ketersediaan } \\
\text { tenaga Kerja }\end{array}$ & $\begin{array}{l}\text { Kontrak A, pasal } 64 \\
\text { Kontrak B, pasal } 64 \\
\text { Kontrak C, pasal } 64 \\
\text { Kontrak D, pasal } 64 \\
\text { Kontrak E, pasal } 64 \\
\end{array}$ & $\begin{array}{l}\text { Pasal 6. Staf dan Tenaga Kerja } \\
\text { Sub-Kalusula 6.9 Personil Kontraktor }\end{array}$ \\
\hline $\mathrm{X} 19$ & $\begin{array}{l}\text { Ketersediaan } \\
\text { Pabrik \& } \\
\text { peralatan }\end{array}$ & $\begin{array}{l}\text { Kontrak A, pasal } 20 \\
\text { Kontrak B, pasal } 20 \\
\text { Kontrak C, pasal } 20 \\
\text { Kontrak D, pasal } 20 \\
\text { Kontrak E, pasal } 20\end{array}$ & $\begin{array}{l}\text { Pasal 4. Kontraktor } \\
\text { Sub-Kalusula 4.16 Pengangkutan } \\
\text { Barang-barang } \\
\text { Sub-Kalusula 4.17 Peralatan } \\
\text { Kontraktor }\end{array}$ \\
\hline $\mathrm{X} 1$ & $\begin{array}{l}\text { Gambar yang } \\
\text { belum final }\end{array}$ & $\begin{array}{l}\text { Kontrak A, pasal } 30,63 \\
\text { Kontrak B, pasal } 30,63 \\
\text { Kontrak C, pasal } 30,63 \\
\text { Kontrak D, pasal } 30,63 \\
\text { Kontrak E, pasal } 30,63\end{array}$ & 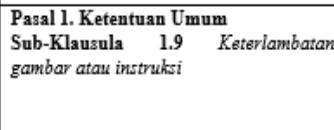 \\
\hline $\mathrm{X} 22$ & $\begin{array}{l}\text { Pekerjaan yang } \\
\text { rusak / cacat } \\
\text { mutu }\end{array}$ & $\begin{array}{l}\text { Kontrak A, pasal } 73 \\
\text { Kontrak B, pasal } 73 \\
\text { Kontrak C, pasal } 73 \\
\text { Kontrak D, pasal } 73 \\
\text { Kontrak E, pasal } 73\end{array}$ & $\begin{array}{l}\text { Pasal 11. Tanggung Jawab Atas Cacat } \\
\text { Mutu } \\
\text { Sub-Klausula ll.1 Penyelesaian } \\
\text { Pekerjaan yang Belum Selesai dan } \\
\text { Perbaikan Cacat Mutu, Sub-Klausula } \\
\text { 11.2 Biaya Perbaikan Cacat Mutu, } \\
\text { Sub-Klausula 11.3 Perpanjangan Masa } \\
\text { Pemberitahuan Cacat Mutu, Sub- } \\
\text { Klausula 11.4 Kegagalan Memperbaiki } \\
\text { Cacat Mutu }\end{array}$ \\
\hline $\mathrm{X} 9$ & $\begin{array}{l}\text { Penghentian } \\
\text { pekerjaan }\end{array}$ & $\begin{array}{l}\text { Kontrak A, pasal } 28,63 \\
\text { Kontrak B, pasal } 28,63 \\
\text { Kontrak C, pasal } 28,63 \\
\text { Kontrak D, pasal } 28,63 \\
\text { Kontrak E, pasal } 28,63\end{array}$ & $\begin{array}{l}\text { Pasal 8. Tanggal Mulai Pekerjaan, } \\
\text { Keterlambatan dan Penghentian } \\
\text { Sub-Klausula 8.8 Penghentian } \\
\text { Pekerjaan, Sub-Klausula 8.9 } \\
\text { Konsekuensi Penghentian, Sub- } \\
\text { Klausula 8.10 Pembayaran untuk } \\
\text { Instalasi mesin dan Bahan-bahan pada } \\
\text { saat Penghentian, Sub-Klausula 8.11 } \\
\text { Penghentian Pekerjaan yang } \\
\text { Berkepanjangan }\end{array}$ \\
\hline
\end{tabular}

\section{Ketersediaan Tenaga Kerja}

Apabila dilakukan perbandingan antara kontrak konstruksi APBD Halmahera Utara Maluku Utara dengan FIDIC Red Book 1999, maka terlihat bahwa terdapat beberapa perbedaan yang perlu diperhatikan. Perbedaan yang pertama adalah pada kontrak konstruksi APBD pada pasal 64.2 dan pasal 64.3 dimana mengatur penyedia jasa untuk wajib memiliki persetujuan tertulis dari PPK selaku pengguna jasa jika ingin mengganti personil dari kontraktor dan penyedia harus melakukan pengajuan jika ingin melakukan pergantian personil 
inti kontraktor kepada PPK selaku pengguna jasa, sedangkan pada FIDIC Red Book 1999 pada pasal 6.9 dan pasal 6.10 dimana pada pasal tersebut tidak mengatur mengenai pergantian personil namun hanya mengatur mengenai pemindahan personil kontraktor dan tidak mengatur atau tidak perlu meminta ijin tertulis jika penyedia jasa ingin melakukan pemindahan personil inti dari penyedia jasa, namun penyedia harus membuat laporan setiap bulan kalender mengenai jumlah kelompok personil kontraktor pada enjinir. Jika dilihat dari perbedaan pertama dimana pada kontrak APBD lebih rinci mengatur mengenai pergantian personil kontrak dengan mengikut sertakan pengguna jasa dalam hal ini namun tidak mengatur mengenai pemindahan personil kontraktor, namun berbanding terbalik pada FIDIC Red Book 1999 hanya mengatur mengenai pemindahan personil kontraktor dan lebih memberikan hak kepada kontraktor mengenai pergantian personil intinya namun harus selalu memberikan laporan setiap bulan mengenai jumlah personil yang ada di lapangan.

Perbedaan kedua yang terlihat pada kontrak konstruksi APBD pada pasal 64.5 dan 64.6 dimana PPK dapat meminta penyedia jasa untuk melakukan pergantian personil kontraktor jika tidak mampu melakukan pekerjaan dengan baik, berkelakuan tidak baik, dan mengabaikan pekerjaan yang menjadi tugasnya. Pada pasal 64.5 juga mengatur agar penyedia dapat menyediakan personil pengganti dalam waktu 7 hari sejak permintaan penggantian personil oleh PPK. Dan juga pada pasal 64.6 dimana mengatur mengenai biaya penggantian personil yang diminta oleh PPK, tanpa ada biaya tambahan apapun kepada PPK. Sedangkan pada FIDIC Red Book 1999 pada pasal 6.9 dimana enjinir dapat meminta kontraktor agar memindahkan personilnya jika terus melakukan kesalahan atau kurang berhatihati, melakukan tugas secara tidak tanggung jawab, gagal memenuhi ketentuan kontrak, dan terus melakukan tindakan yang membahayakan keamanan, kesehatan atau pelindungan terhadap lingkungan. Pada FIDIC tidak mengatur mengenai biaya akibat pemindahan atau pergantian personil yang diminta oleh enjinir dan tidak mengatur mengenai batas waktu untuk menyediakan personil pengganti akibat permintaan pemindahan ataupun pergantian yang diminta oleh enjinir. Jika dilihat dari perbedaan kedua dimana pada Kontrak APBD mengatur lebih rinci mengenai dampak dari permintaan pergantian personil yang diminta oleh PPK atau pengguna jasa kepada penyedia jasa, namun tidak mengatur mengenai pemindahan personil. Pada FIDIC hanya mengatur hal-hal yang dapat mengakibatkan terjadinya pemindahan personil kontrak dan tidak mengatur mengenai pergantian personil, dan juga tidak mengatur secara rinci mengenai akibat dari permintaan pemindahan personil oleh enjinir atau penyedia jasa baik dalam hal biaya dan batas waktu untuk menyediakan pengganti personil.

Perbedaan ketiga yang terlihat pada kontrak konstruksi APBD pada pasal 64.7 dimana mengatur agar personil inti berkewajiban untuk menjaga kerahasiaan pekerjaan, dan juga jika diperlakukan oleh PPK maka personil inti dapat disyaratkan untuk menjaga kerahasiaan pekerjaan dibawah sumpah sedangkan pada FIDIC Red Book 1999 pada pasal 6 tentang staf dan tenaga kerja tidak diatur mengenai hal ini.

Dari perbandingan kedua jenis kontrak yang mengatur mengenai ketersediaan tenaga kerja dapat dilihat pada kontrak APBD dimana jika penyedia jasa selaku kontraktor 
ingin melakukan pergantian personil inti ataupun penggantian personil inti yang diminta oleh PPK maka kontraktor wajib memiliki persetujuan dari PPK dari hal ini dapat dilihat bahwa akan berpotensi menimbulkan masalah dimana setiap pergantian personil kontraktor harus meminta persetujuan kepada PPK hal ini akan berdampak pada ketersediaan personil kontraktor di lapangan jika PPK tidak menyetujui pergantian personil dengan alasan yang telah diberikan kontraktor, dimana proses pengawasan pekerjaan yang dilakukan kontraktor akan terhambat dan dapat menimbulkan penyelesaian pekerjaan yang terlambat maupun hasil dari pekerjaan yang kurang baik dilapangan. Sedangkan pada FIDIC penyedia jasa tidak perlu meminta persetujuan tertulis jika ingin melakukan pergantian personil sehingga kontraktor bebas melakukan pergantian personil sesuai dengan kebutuhan pekerjaan di lapangan, namun penyedia jasa harus melaporkan personil yang diganti sesuai dengan kualifikasi yang telah ditentukan dan penyedia jasa harus membuat laporan tentang jumlah personil yang ada di lapangan.

\section{Ketersediaan Pabrik dan Peralatan}

Apabila dilakukan perbandingan antara kontrak konstruksi APBD Halmahera Utara Maluku Utara dengan FIDIC Red Book 1999, maka terlihat bahwa terdapat beberapa perbedaan yang perlu diperhatikan. Perbedaan yang pertama adalah pada kontrak konstruksi APBD pada pasal 20.1 dimana penyedia melakukan mobilisasi peralatan, personil, dan fasilitas paling lambat harus sudah mulai dilaksanakan dalam waktu 30 hari sejak SPMK (Surat Perintah Mulai Kerja), Sedangkan pada FIDIC Red Book 1999 pada pasal 4.16 mengatur kontraktor harus memberitahukan kepada enjinir tidak kurang dari 21 hari sebelum kontraktor melakukan mobilisasi ataupun istalasi mesin, fasilitas, dan barang-barang diangkut ke lapangan. Dan juga pada FIDIC Red Book 1999 mengatur lebih rinci mengenai tanggung jawab mobilisasi, instalasi mesin maupu pengangkutan barang-barang dan fasilitas ke lapangan dimana pada FIDIC kontraktor bertanggung jawab penuh atas pengepakan, pemuatan, pengangkutan penerimaan, penurunan, penyimpanan dan perlindungan seluruh barang-barang yang diperlukan untuk pekerjaan. Kontraktor juga harus membayar ganti rugi dan menghindarkan pengguna jasa dari kerugian akibat kerusakan, kehilangan dan pengeluaran (termasuk biaya dan pengeluaran legal) yang disebabkan oleh pengangkutan barang-barang, dan harus menegosiasikan dan membayar seluruh klaim yang timbul karena pengangkutan tersebut.

Perbedaan kedua yang terlihat pada kontrak konstruksi APBD dengan FIDIC Red Book 1999 dimana pada FIDIC mengatur mengenai peralatan kontraktor di lapangan seperti pada pasal 4.17, yaitu kontraktor harus bertanggung jawab atas seluruh peralatan kontraktor di lapangan dan setiap peralatan kontraktor harus benar-benar diperuntukkan hanya bagi pelaksanaan pekerjaan dan kontraktor tidak boleh memindahkan semua peralatan utama kontraktor dari lapangan tanpa persetujuan enjinir. Sedangkan pada kontrak APBD tidak diatur mengenai hal-hal di atas.

Dari perbandingan kedua jenis kontrak yang mengatur mengenai ketersediaan pabrik dan peralatan dapat dilihat pada kontrak APBD dimana hanya mengatur mengenai waktu mobilisasi peralatan, fasilitas, dan barang-barang, namun tidak mengatur tentang dampak dari proses ketersediaan 
peralatan, fasilitas, dan barang-barang dimana hal ini dapat berpotensi menimbulkan masalah pada saat proses mobilisasi peralatan, fasilitas, dan barangbarang untuk ketersediaan di lapangan dikarenakan pada kontrak APBD tidak mengatur mengenai hak dan kewajiban dari proses tersebut. Sedangkan pada FIDIC mengatur lebih rinci mengenai waktu mobilisasi serta dampak dari proses mobilisasi peralatan, fasilitas, dan barangbarang dan juga mengatur tentang hak dan kewajiban dalam proses mobilisasi ke lapangan proyek, pada FIDIC juga mengatur mengenai ketersediaan peralatan, fasilitas, dan barang-barang di lapangan dimana setiap peralatan dan fasilitas yang ada di lapangan harus sesuai dengan kebutuhan pekerjaan di lapangan dan juga kontraktor harus meminta persetujuan untuk memindahkan peralatan, fasilitas, dan barang-barang yang ada di lapangan.

\section{Gambar Yang Belum Final / Keterlambatan Gambar atau Instruksi}

Apabila dilakukan perbandingan antara kontrak konstruksi APBD Halmahera Utara Maluku Utara dengan FIDIC Red Book 1999, maka terlihat bahwa terdapat perbedaan yang perlu diperhatikan perbedaan yang pertama adalah mengenai pembayaran ganti rugi akibat keterlambatan gambar atau instruksi dimana pada FIDIC mengatur dampak dari masalah keterlambatan gambar dan instruksi yaitu pengguna jasa berkewajiban memberikan perpanjangan waktu penyelesaian pekerjaan atau membayar ganti rugi di tambah keuntungan yang wajar kepada kontraktor. Akan tetapi kegagalan enjinir disebabkan oleh kesalahan atau keterlambatan kontraktor, termasuk kesalahan dalam penyampaian, dari suatu dokumen kontraktor, kontraktor tidak berhak atas perpanjangan waktu penyelesaian pekerjaan, biaya atau keuntungan tersebut. Sedangkan dalam kontrak APBD dimana PPK selaku pengguna jasa berkewajiban memberikan perpanjangan waktu penyelesaian pekerjaan atau membayar ganti rugi kepada kontraktor. akan tetapi jika penyedia gagal atau lalai memberikan peringatan dini dalam mengantisipasi atau mengatasi dampak dari masalah keterlambatan gambar atau instruksi.

Dari perbandingan kedua jenis kontrak yang mengatur mengenai keterlambatan gambar dan instruksi dapat dilihat pada kontrak APBD dimana mengatur mengenai dampak dari masalah keterlambatan gambar atau instruksi yaitu perpanjangan waktu penyelesaian pekerjaan jika dinilai hanya berdampak pada lamanya penyelesaian pekerjaan dan diberikan ganti rugi jika berdampak pada kerugian biaya kontraktor, dan tidak mengatur mengenai keuntungan kontraktor yang hilang akibat masalah ini. Hal ini dapat berpotensi menimbulkan masalah terhadap penyedia dan pengguna jasa. sedangkan pada FIDIC mengatur mengenai perpanjangan waktu penyelesaian pekerjaan, ganti rugi dan ditambahkan keuntungan yang wajar yang harus di dapatkan oleh kontraktor akibat dari keterlambatan gambar dan instruksi dari enjinir selaku pengguna jasa.

\section{Pekerjaan yang Rusak atau Cacat Mutu}

Apabila dilakukan perbandingan antara kontrak konstruksi APBD Halmahera Utara Maluku Utara dengan FIDIC Red Book 1999, maka terlihat bahwa terdapat perbedaan yang perlu diperhatikan. Perbedaan yang pertama adalah pada FIDIC Red Book 1999 dimana mengatur beberapa hal yang tidak diatur oleh kontrak konstruksi APBD, yaitu apabila ditemukan cacat mutu atau kerusakan, maka enjinir selaku pengguna 
jasa harus sesegara mungkin memberitahukan kepada kontraktor dan harus menyelesaikan perbaikan cacat mutu atau kerusakan sebelum masa pemberitahuan cacat mutu atau kerusakan berakhir. Dimana pengguna jasa berhak atas suatu perpanjangan masa pemberitahuan cacat mutu untuk pekerjaan atau bagian pekerjaan, (apabila hal ini terjadi, dan setelah serah terima), karena cacat mutu atau kerusakan. Akan tetapi suatu masa pemberitahuan cacat mutu tidaklah dapat di perpanjang lebih dari dua tahun. apabila pengiriman dan/atau pemasangan suatu instalasi mesin dan/atau bahan-bahan dihentikan berdasarkan Sub-Klausula 8.8 [Penghentian Pekerjaan] atau Sub-Klausula 16.1 [Hak Kontraktor untuk Menghentikan Pekerjaan], kewajiban kontraktor berdasarkan klasula ini tidak boleh diberlakukan untuk cacat mutu atau kerusakan yang terjadi pada masa lebih dari dua tahun setelah masa pemberitahuan cacat mutu untuk instalasi mesin dan/atau bahan-bahan seharusnya berakhir. Pada kontrak FIDIC juga mengatur mengenai hak dan kewajiban dari pengguna jasa maupun penyedia jasa dalam menghadapi masalah cacat mutu atau kerusakan dari suatu pekerjaan ataupun instalasi mesin, dimana setiap pekerjaan cacat mutu atau kerusakan yang terjadi akibat kontraktor maka sepenuhnya risiko, dan biaya menjadi tanggung jawab dari kontraktor. Namun jika cacat mutu atau kerusakan pekerjaan di sebabkan oleh hal lain maka Sub-Klausula 13.3 [Prosedur Variasi] pada FIDIC akan dikeluarkan. Lebih lanjut FIDIC juga mengatur mengenai konsekuensi jika kontraktor gagal memperbaiki cacat mutu atau kerusakan sesauai dengan waktu yang telah diberikan, maka pengguna jasa dapat melaksanakan pekerjaan sendiri atau oleh pihak lain dengan seluruh biaya pekerjaan di tanggung oleh kontraktor, namun kontraktor tidak bertanggung jawab atas pekerjaan perbaikan cacat mutu atau kerusakan yang di kerjakan oleh pengguna jasa maupun pihak lain. Atau pengguna jasa juga dapat mengurangi harga kontrak dari pekerjaan yang mengalami cacat mutu. Pengguna jasa juga bisa memutuskan kontrak secara keseluruhan atau untuk bagian utama dari suatu pekerjaan yang mengalami cacat mutu jika pengguna jasa secara substansial kehilangan keseluruhan manfaat dari pekerjaan atau bagian utama dari pekerjaan. pengguna jasa selanjutnya berhak untuk memperoleh semua biaya yang dikeluarkan untuk pekerjaan atau sebagian dari pekerjaan ditambah beban pendanaan dan biaya pembongkaran, pembersihan lapangan dan pengembalian instalasi mesin dan bahan-bahan kepada kontraktor. Sedangkan pada kontrak konstruksi APBD tidak diatur secara rinci mengenai hak dan tanggung jawab pengguna jasa dan penyedia jasa dalam menghadapi masalah cacat mutu atau kerusakan. Pada kontrak konstruksi APBD mengatur bahwa PPK atau pengawas akan memberitahukan secara tertulis dan dapat memerintahkan penyedia untuk menemukan ataupun mengungkapkan cacat mutu yang di temukan oleh PPK, penyedia juga bertanggung jawab atas perbaikan cacat mutu selama masa kontrak dan masa pemeliharaan. Selanjutnya jika penyedia tidak memperbaiki cacat mutu dalam jangka waktu yang ditentukan, maka PPK dapat melakukan perbaikan ataupun menunjuk pihak ketiga untuk melakukan perbaikan cacat mutu atau kerusakan tersebut. Penyedia bertanggung jawab mengganti biaya perbaikan cacat mutu yang diminta oleh PPK secara tertulis dengan cara PPK dapat memotong biaya pembayaran tagihan, uang retensi, atau pencairan surat jaminan 
pemeliharaan atau jika tidak ada maka biaya penggantian akan diperhitungkan sebagai utang penyedia kepada PPK yang telah jatuh tempo. PPK juga dapat mengenakan denda keterlambatan untuk setiap keterlambatan perbaikan cacat mutu, dan mendaftar hitamkan penyedia.

Dari perbandingan kedua jenis kontrak yang mengatur mengenai pekerjaan yang rusak atau cacat mutu dapat dilihat pada kontrak APBD dimana tidak mengatur mengenai sebab dan akibat jika terjadinya pekerjaan yang rusak atau cacat mutu sehingga hal ini bisa berpotensi menimbulkan masalah antara pengguna jasa dan penyedia jasa. Sedangkan pada FIDIC Red Book 1999 mengatur secara rinci mengenai sebab dan akibat jika terjadinya pekerjaan yang rusak atau cacat mutu serta mengatur hak dan kewajiban dari penyedia jasa dan pengguna jasa sehingga jika terjadi masalah pekerjaan yang rusak atau cacat mutu sudah cukup jelas dalam pasal FIDIC yang mengatur mengenai cacat mutu atau kerusakan pekerjaan.

\section{Penghentian Pekerjaan}

Apabila dilakukan perbandingan antara kontrak konstruksi APBD Halmahera Utara Maluku Utara dengan FIDIC Red Book 1999, maka terlihat bahwa terdapat perbedaan yang perlu diperhatikan perbedaan yang pertama adalah mengenai penghentian pekerjaan dimana pada kontrak konstruksi APBD hanya mengatur bahwa pengawas pekerjaan dapat memerintahkan secara tertulis penyedia untuk menunda pelaksanaan pekerjaan dimana setiap perintah penundaan ini harus segera ditembuskan kepada PPK dan mengatur mengenai hak yang di dapat oleh kontraktor jika penghentian pekerjaan yang dilakukan oleh pengguna jasa dapat merugikan kontraktor, dimana jika penghentian pekerjaan mengakibatkan pengeluaran tambahan dan/atau keterlambatan penyelesaian pekerjaan maka PPK berkewajiban untuk membayar ganti rugi atau memberikan perpanjangan waktu penyelesaian pekerjaan. Sedangkan pada FIDIC Red Book 1999 mengatur hak dan kewajiban kontraktor jika terjadi penghentian pekerjaan dimana pada FIDIC pasal 8.8 penghentian pekerjaan bahwa enjinir setiap saat menginstruksikan kontraktor untuk menghentikan kemajuan suatu bagian dari pekerjaan atau seluruh pekerjaan. Dan kewajiban kontraktor Pada masa penghentian pekerjaan tersebut, kontraktor harus melindungi, menyimpan dan mengamankan bagian dari pekerjaan atau seluruh pekerjaan dari penurunan mutu, kehilangan atau kerusakan. Namun apabila penghentian pekerjaan dikarenakan tanggung jawab kontraktor maka SubKlausula 8.9, 8.10 dan 8.11 pada FIDIC Red Book 1999 tidak berlaku. Pada Sub-Klausula 8.9, 8.10 dan 8.11 mengatur lebih rinci mengenai hak dan kewajiban pengguna jasa dan penyedia jasa selama penghentian pekerjaan yang terjadi. Yaitu apabila kontraktor mengalami keterlambatan atau mengeluarkan biaya akibat instruksi penghentian pekerjaan dari enjinir maka kontraktor berhak berdasarkan Subklausula 20.1 [Klaim Kontraktor] yaitu mendapatkan perpanjangan waktu penyelesaian pekerjaan apabila terlambat atau terhambat, mendapatkan pembayaran untuk biaya tersebut dan harus dimasukkan kedalam kontrak.

Dari perbandingan kedua jenis kontrak yang mengatur mengenai penghentian pekerjaan dapat dilihat pada kontrak APBD dimana tidak mengatur mengenai sebab dan akibat jika terjadinya penghentian pekerjaan apakah di sebabkan oleh penyedia jasa atau pengguna jasa. 
Hal ini bisa berpotensi menimbulkan masalah antara pengguna jasa dan penyedia jasa dikarenakan tidak diatur secara rinci mengenai hak dan kewajiban jika terjadi penghentian pekerjaan akibat kesalahan dari kontraktor ataupun instruksi dari enjinir. Sedangkan pada FIDIC Red Book 1999 mengatur secara rinci mengenai sebab dan akibat jika terjadinya penghentian pekerjaan. Dimana bisa dilihat pada SubKlausula 8.8, 8.9, 8.10 dan 8.11 bahwa kewajiban kontraktor selama penghentian pekerjaan harus harus melindungi, menyimpan dan mengamankan bagian dari pekerjaan atau seluruh pekerjaan dari penurunan mutu, kehilangan atau kerusakan. Agar tidak timbul masalah yang lain seperti kerusakan ataupun cacat mutu. kemudian FIDIC juga mengatur mengenai waktu penghentian pekerjaan agar setiap pihak bisa mendapatkan hak dan melakukan kewajibannya. Dimana kontraktor berhak atas pembayaran jika penghentian pekerjaan lebih dari 28 hari kemudian jika penghentian berlanjut hingga melebihi 84 hari kontraktor dapat meminta izin untuk melanjutkan pekerjaan. Apabila dalam waktu 28 hari sejak diterimanya permohonan enjinir tidak memberikan izin maka kontraktor dapat, dengan menyampaikan pemberitahuan kepada enjinir, memperlakukan penghentian sebagai suatu pengurangan berdasarkan Klausla 13 [Variasi dan Penyesuaian] atas bagian dari pekerjaan yang terpengaruh. Apabila penghentian mempengaruhi pekerjaan secara keseluruhan, kontraktor dapat menyampaikan pemberitahuan pemutusan kontrak berdasarkan SubKlausula 16.2 [Pemutusan oleh Kontraktor].

\section{Kesimpulan}

Berdasarkan rumusan masalah yang dibahas pada penelitian ini, perlu diketahui faktor-faktor dominan apa saja yang berpotensi terjadinya klaim dan sengketa yang berkaitan pada pasal-pasal kontrak konstruksi APBD kabupaten Halmahera Utara provinsi Maluku Utara. Setelah dilakukan analisis statistik menggunakan analisis faktor didapat;

1. Faktor-faktor dominan yang berpotensi terjadinya klaim dan sengketa yang berkaitan pada pasal-pasal kontrak konstruksi APBD kabupaten Halmahera Utara provinsi Maluku Utara adalah sebagai berikut:

a. Faktor ketersedian tenaga kerja dengan nilai dominan sebesar $90 \%$ dimana pasal yang mengatur pada kontrak Konstruksi APBD kabupaten Halmahera Utara provinsi Maluku Utara. Pada Kontrak A, B, C, D, E diatur pada pasal 64

b. Faktor ketersedian pabrik dan peralatan dengan nilai dominan sebesar 88,6 \% dimana pasal yang mengatur pada kontrak konstruksi APBD kabupaten Halmahera Utara provinsi Maluku Utara. Pada Kontrak A, B, C, D, E diatur pada pasal 20

c. Faktor gambar yang belum final atau keterlambatan gambar atau Instruksi dengan nilai dominan sebesar 78,2\% dimana pasal yang mengatur pada kontrak konstruksi APBD kabupaten Halmahera Utara provinsi Maluku Utara. Pada Kontrak A, B, C, D, E diatur pada pasal 30 dan 63

d. Faktor pekerjaan yang rusak atau cacat mutu dengan nilai dominan sebesar 76,8 \% dimana pasal yang mengatur pada kontrak konstruksi APBD kabupaten Halmahera Utara provinsi Maluku Utara. Pada Kontrak A, B, C, D, E diatur pada pasal 73

e. Faktor penghentian pekerjaan dengan nilai dominan sebesar $74 \%$ 
dimana pasal yang mengatur pada kontrak konstruksi APBD kabupaten Halmahera Utara provinsi Maluku Utara. Pada Kontrak A, B, C, D, E diatur pada pasal 28 dan 63

2. Setelah mendapatkan faktor-faktor dominan, dilakukan analisis kualitatif untuk membandingkan klausula-klausula yang berhubungan dan mengatur faktor-faktor dominan tersebut pada kontrak konstruksi APBD kabupaten Halmahera Utara provinsi Maluku Utara dan FIDIC Red Book Tahun 1999, didapatkan bahwa dari kelima faktor yaitu ketersedian tenaga kerja, ketersediaan pabrik dan peralatan, keterlambatan gambar dan instruksi/gambar yang belum final, pekerjaan yang rusak/ cacat mutu, dan pengehentian pekerjaan. Dimana pada kontrak konstruksi APBD tidak mengatur secara rinci mengenai hak dan kewajiban serta tanggung jawab dari pihak-pihak yang terlibat sedangkan pada FIDIC Red Book 1999 sudah sangat rinci mengatur mengenai hal tersebut.

\section{Daftar Pustaka}

Nurnaningsih. 2012. Mediasi Alternatif Penyelesaian Sengketa Perdata di Pengadilan. Jakarta: PT Raja Grafindo.

Federation Internationale des IngenierusConseils. 1999. Conditions of Contract for Construction. FIDIC:Geneve, Switzerland.

Federation Internationale des IngenierusConseils. 2010. Persyaratan Kontrak Untuk Pelaksanaan Konstruksi (Edisi Bahasa Indonesia FIDIC Conditions of Contract for Construction 1999). FIDIC,LPJK,INKINDO.
Garner, Brian A. 2004. Black's Law Dictionary, Tenth Edition, Thomson Reuters, St.Paul-Minnesota, dalam Hardjomuljadi, Sarwono. 2014. Buku Kesatu: Pengantar Kontrak Konstruksi FIDIC Conditions of Contract. Bandung: Logoz Publishing.

Hardjomuljadi, Sarwono et.al. 2006. Strategi Klaim Konstruksi Berdasarkan FIDIC Conditions of Contract. Pola Grade: Jakarta.

Hardjomuljadi, $\quad$ Sarwono. 2010. "Pemahaman Kontrak Konstruksi Internasional Terhadap Tantangan Era Globalisasi". Jurnal Konstruksia, Vol. 2 No. 1, Jakarta.

Hardjomuljadi, Sarwono. 2010. "The Main Causal Factors of Construction Claims Under FIDIC Contract in Indonesia". Presented at FIDIC-JICA, International Construction Management Training, Jakarta 26-29 July 2010.

Hardjomuljadi, Sarwono. 2014. "Factor Analysis on Causal of Construction Claims and Disputes in Indonesia". International Journal of Applied Engineering Research Vol. 10 No. 9.

Hardjomuljadi, Sarwono. 2014. "Permasalahan Klaim Konstruksi di Proyek Institusi Pemerintah". Seminar Konstruksi Indonesia, 6 November 2014.

Hardjomuljadi, Sarwono. 2014. Buku Kesatu: Pengantar Kontrak Konstruksi FIDIC Conditions of Contract. Bandung: Logoz Publishing.

Hardjomuljadi, Sarwono. 2015. Buku Kedua: Manajemen Klaim Konstruksi FIDIC Conditions of Contract. Bandung: Logoz Publishing.

Hardjomuljadi, Sarwono. 2016. Buku Ketiga: Alternatif Penyelesaian Sengketa Konstruksi di Indonesia. Bandung: Logoz Publishing. 
Hansen, Seng. 2018. Manajemen Kontrak Konstruksi: Pedoman Praktis dalam Mengelola Proyek Konstruksi. Jakarta:PT Gramedia Pustaka Utama.

Krisnawenda, N. 2016. Proses Penyelesaian Sengketa Bisnis melalui Arbitrase \& APS/ADR. Dipresentasikan pada tanggal 22 September 2016, di Mataram.

Kenny K. 2019. Analisis Faktor Penyebab Klaim Pada FIDIC Design-Build Tahun 2017 (Dengan Refrensi FIDIC DesignBuild Tahun 1999). Tesis Universitas Tarumanagara maret 2019

Mardiasmo. (2004). Otonomi dan Manajemen Keuangan Daerah. Yogyakarta: Andi

Maritz, Marthinus J, dan Uwe Putlitz. Standard Form Construction Contracts: Why the Need for Regular Changes?. Pretoria: University of Pretoria.

Masruchiyah, Nieke. 2018. Penyelesaian Sengketa Kontrak Kerja Konstruksi Melalui Arbitrase \& APS. PT RajaGrafindo Persada:Depok.

Neuman, W. L. 2014. Social Research Methods: Qualitative and Quantitative Approaches; Relevance of Social Research, Vol. 8.

Peraturan Pemerintah RI No. 58 Tahun 2005 tentang Pengelolaan Keuangan Daerah yaitu Anggaran Pendapatan dan Belanja Daerah

Pemerintah Republik Indonesia. 1999. Undang-Undang Republik Indonesia Nomor 18 tahun 1999 tentang Jasa Konstruksi.

Republik Indonesia. 1999. Undang-Undang Republik Indonesia Nomor 30 Tahun 1999 Tentang Arbitrase dan Alternatif Penyelesaian Sengketa. Lembaran Negara RI Tahun 1999. Sekretariat Negara.

Republik Indonesia. 2000. Peraturan Pemerintah Republik Indonesia Nomor
30 Tahun $2000 \quad$ Tentang

Penyelenggaraan Pembinaan Jasa Konstruksi. Lembaran Negara RI Tahun 2000. Sekretariat Negara.

Ramadi, Takdir. 2010. Mediasi: Penyelesaian Sengketa Melalui Pendekatan Mufakat. Depok: Rajawali Press.

Republik Indonesia. 2014. Undang-Undang Republik Indonesia Nomor 3 Tahun 2014 Tentang Perindustrian. Lembaran Negara RI Tahun 2014. Sekretariat Negara.

Subekti, R. 2001, Kitab Undang-Undang Hukum Perdata, Buku III, Pradjna Paramitha, Jakarta.

Sugiyono. 2007 "Metode Penelitian

Pendidikan Pendekatan Kuantitatif, Kualitatif, dan R\&D”. Bandung: Alfabeta. Sugiyono. 2017. Metode Penelitian \& Pengembangan Untuk Bidang: Pendidikan, Manajemen, Sosial, Teknik. Bandung: Alfabeta.

Undang-undang Republik Indonesia Nomor 22 Tahun 1999 Tentang Pemerintahan Daerah. 